\title{
Eocene Monsoon Forests in Central Australia?
}

\author{
David R. Greenwood \\ Botany Department, University of Adelaide, Adelaide, SA 5005, Australia; \\ present address: Department of Environmental Management, \\ St Albans Campus, Victoria University of Technology, \\ PO Box 14428, MMC, Melbourne, Vic. 3000, Australia.
}

\begin{abstract}
The Australian Tertiary plant fossil record documents rainforests of a tropical to temperate character in south-eastern and south-western Australia for much of the Early Tertiary, and also shows the climatically mediated contraction of these rainforests in the mid to Late Tertiary. The fossil record of Australian monsoon forests, that is semi-evergreen to deciduous vine forests and woodlands of the wet-dry tropics, however, is poorly known. Phytogeographic analyses have suggested an immigrant origin for some floral elements of present day monsoon forests in northern Australia, while other elements appear to have a common history with the tropical rainforests sensu stricto and/or the sclerophyllous flora. Early Tertiary macrofloras in northern South Australia may provide some insight into the origins of Australian tropical monsoon forests. The Middle Eocene macrofloras of the Poole Creek palaeochannel, and the ?Eocene-Oligocene silcrete macrofloras of Stuart Creek, both in the vicinity of modern Lake Eyre South, have foliar physiognomic characteristics which distinguish them from both modern rainforest and Eocene-Oligocene floras from south-eastern Australia. Preliminary systematic work on these floras suggests the presence of: (1) elements not associated today with monsoon forests (principally 'rainforest' elements, e.g. Gymnostoma, cf. Lophostemon, cf. Athertonia, Podocarpaceae, ?Cunoniaceae); (2) elements typical of both monsoon forests and other tropical plant communities (e.g. cf. Eucalyptus, cf. Syzygium, and Elaeocarpaceae); (3) elements likely to be reflecting sclerophyllous communities (e.g. cf. Eucalyptus, Banksieae and other Proteaceae); and (4) elements more typically associated with, but not restricted to, monsoon forests (e.g. Brachychiton). The foliar physiognomic and floristic evidence is interpreted as indicating a mosaic of gallery or riverine rainforests, and interfluve sclerophyllous plant communities near Lake Eyre in the Early Tertiary; deciduous forest components are not clearly indicated. Palaeoclimatic analysis of the Eocene Poole Creek floras suggests that rainfall was seasonal in the Lake Eyre area in the Eocene; however, whether this seasonality reflects a monsoonal airflow is not clear.
\end{abstract}

\section{Introduction}

In Australia today, the tropical zone is characterised by a dominance of Eucalyptus spp. woodlands and tree savannas, and grasslands. Rainforests sensu stricto are largely restricted to coastal lowlands and uplands on the east coast and riparian corridors elsewhere. In isolated pockets on Cape York Peninsula, Arnhem Land, and north-western Western Australia (Fig. 1), however, there are developed distinctive closed-canopy forest (so-called 'dry rainforests') and tall-shrub communities where Eucalyptus spp. are rare or more typically absent. These communities are restricted to areas where annual rainfall exceeds $800 \mathrm{~mm}(>600 \mathrm{~mm}$ in WA), often with a distinct monsoonal summer-wet and winter-dry seasonality, and at the drier end of their range are restricted to fire-proof niches and/or local areas of eutrophic soils (Specht 1981; Webb and Tracey 1981). A feature of these 'monsoon forests' or 'vine thickets' is a closed canopy in the wet season, and often a quite open canopy in the dry season due to partial or complete deciduousness. These monsoon forests or vine thickets 


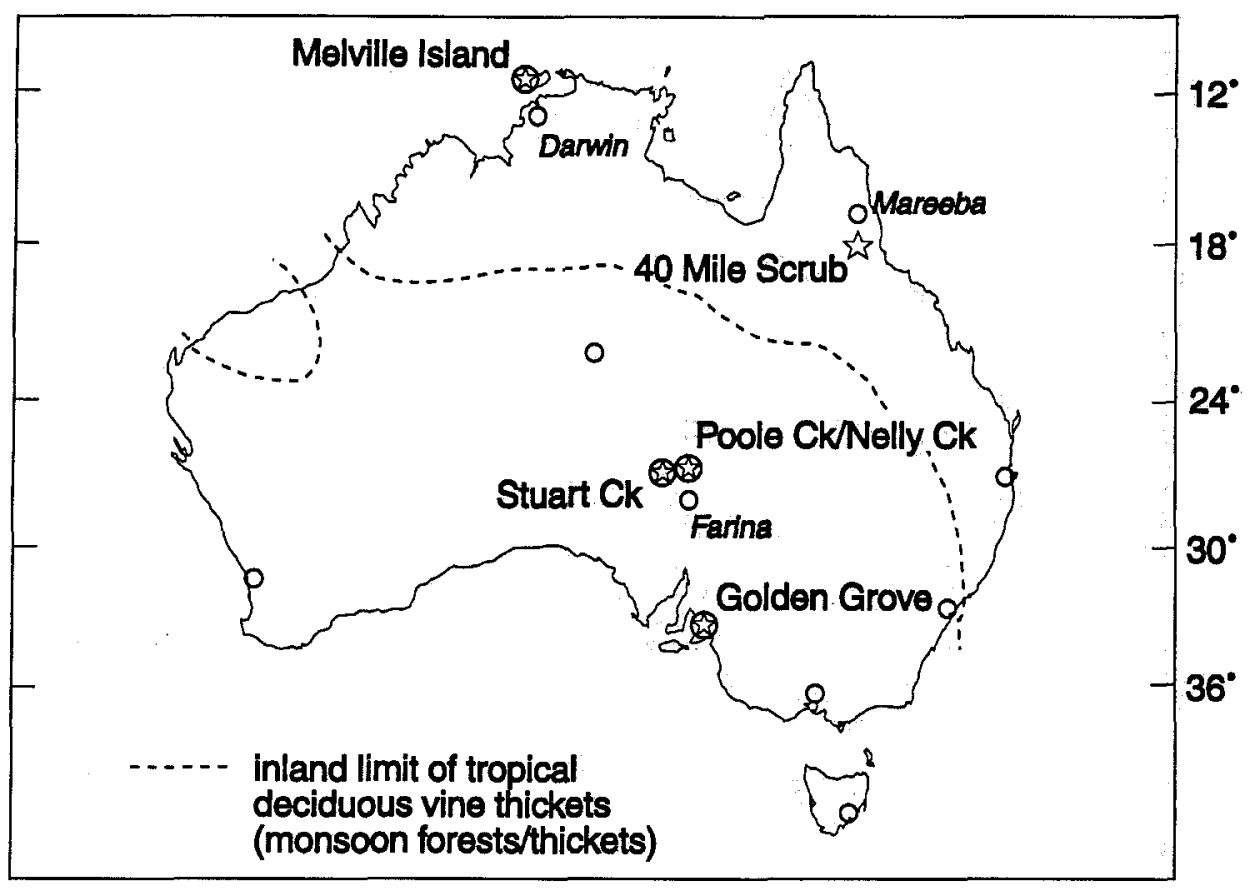

Fig. 1. Map of Australia showing modern distribution of monsoonal semi-deciduous to deciduous vine forests-thickets (SDMVF-DMVT). The location of modern and Eocene-macrofloral sites mentioned in the text are shown.

share floristic, structural and physiognomic traits with rainforest sensu stricto communities in eastern Australia, but retain a distinctive floristic and physiognomic character (Webb and Tracey 1981; Tracey 1982; Webb et al. 1986).

Webb and Tracey (1981) grouped the Australian seasonally dry tropical closed-canopy forests under the all embracing term 'vine forest', noting that much of Australia's rainforests sensu stricto occur under varying degrees of seasonal dryness, with the monsoonal closed canopy communities reflecting the attenuated warm-dry end member of a multidimensional climatic-floristic-edaphic-structural continuum. The term 'rainforest' carries a number of expectations climatically amongst non-botanists, and particularly amongst non-biologists, namely; high rainfall (> $2000 \mathrm{~mm}_{\text {year }}-1$, $>3000 \mathrm{~mm}_{\text {year }}{ }^{-1}$ according to some authors), low or no seasonality of rainfall, and essentially frost free climates (e.g. Beard 1944; Holdridge 1967). In this discussion, the closed forest communities of the markedly seasonal tropics are distinguished from the forests of the main rainforest massifs of the east coast of Australia (which largely match Richard's (1952) definition of rainforest; Webb 1959). In this manner, a broader definition of rainforest than that adopted by Beard (1944) or Holdridge (1967) is used, which while more narrow than that of Webb and Tracey (1981; Webb et al. 1986), is perhaps closer in intent to Richard's (1952) usage and that in common use outside Australia. Monsoon forest is used here, therefore, to encompass the mostly' to wholly deciduous-canopy 'dry rainforests' and 'vine thickets' of the wet-dry tropics of Australia (e.g. deciduous microphyll vine thicket 'Type 4' and semi-deciduous microphyll vine forest 'Type 11' of Webb and Tracey (1981; Tracey 1982), and excludes the higher rainfall ( $>1500$ $\mathrm{mm}$ year $^{-1}$ ) seasonally dry (partially to facultatively deciduous) rainforests (e.g. complex notophyll vine forest 'Type 6'). This distinction is pertinent to this discussion, as palaeovegetational reconstructions which state the presence of 'rainforest' are common in Australian palynology and macrofossil palaeobotany, and while Australian researchers may be aware of the special usage of this term in this country, non-Australian researchers assume the more narrow usage, and climatic implications. 
The tropical and subtropical rainforests sensu stricto of Australia have a long fossil record which clearly supports the hypothesis of an autochthonous, rather than immigrant origin for these plant communities and most of their plant taxa (Kemp 1978; Blackburn 1981; Christophel 1981, 1988; Webb et al. 1986; Truswell 1990; Hill 1992). Recent analyses also indicate close foliar physiognomic matches between south-eastern Australian Early Tertiary macrofloras and rainforests in north Queensland (Christophel and Greenwood 1987, 1988, 1989; Greenwood 1994). Rainforests of similar floristic and foliar physiognomic character to those of modern subtropical to tropical Australia are therefore considered to have occupied much of the Early Tertiary (mainly Eocene) lowlands of southern and east coastal Australia, although palynological analyses indicate that forests rich in floristic elements now considered typical of temperate rainforests (e.g. Nothofagus) are likely to have occupied significant parts of the same landscape (Christophel and Greenwood 1989; Truswell 1990; Greenwood 1991 1994; Hill 1992). Oligocene to Miocene macrofloras and microfloras, however, document a shift towards cooler (from Mesothermal to Megathermal and Mesothermal, to Mesothermal and Microthermal; sensu Nix 1982) more seasonal climates in south-eastern Australia at these times than in the Eocene, and the displacement of tropical elements by temperate floristic elements (Christophel 1988; Christophel and Greenwood 1989; Hill 1992; Greenwood 1994). Limited microfloral, macrofloral and sedimentological evidence from central Australia suggests that seasonally dry climates may have appeared earlier in the centre (e.g. Wopfner et al. 1974; Kemp 1978, 1981; Martin 1982, 1990, 1993; Lange 1982; Truswell and Harris 1982; Quilty 1984), and perhaps also in the south-west (e.g. Hill and Merrifield 1993) and north (Pole and Bowman 1994), than in the south-east of the continent.

The pre-Holocene fossil record of non-rainforest plant communities in Australia (such as sclerophyllous and monsoonal semi-deciduous to deciduous forests) is quite limited, being largely restricted to anecdotal macrofloral accounts (e.g. Lange 1978a; White 1978; Pole and Bowman 1994), and limited palynological evidence (Martin 1978, 1982, 1990; Truswell et al. 1987; Truswell 1990; Luly 1994). Discussion of the evolutionary history of the nonrainforest formations of Australia is therefore largely restricted to analyses of phytogeographical patterns (e.g. Specht 1981; Webb and Tracey 1981; Webb et al. 1986; Crisp et al. this volume). Of particular interest is the much larger group of shared genera (e.g. Adansonia, the boab or baobab, Bombax (both Bombaceae), and Cochlospermum, the kapok (Cochlospermaceae)) and even species (e.g. Gyrocarpus americanus, Hernandiaceae) between monsoonal forests in Australia (and particularly north-west Western Australia) and both South-east Asian and African wet-dry tropical forests, than between Australian and Asian-African rainforests (Specht 1981; Webb and Tracey 1981). It is clear that a degree of shared inheritence as well as later floristic mixing has shaped the phytogeography of both the monsoonal forests and the rainforests of Australia (Webb and Tracey 1981; Webb et al. 1986; Truswell et al. 1987). The question remains therefore, as to whether Australian deciduous, tropical forests and vine thickets share a common history with the rainforests, or a history of floristic invasion from the monsoon forests of South-east Asia.

A geographically extensive suite of leaf and fruit macrofloras from the southern Lake Eyre Basin, termed the Poole Creek palaeochannel (Fig. 1), and the proximal Stuart Creek macroflora (?Eocene-Oligocene, Billa Kalina Basin) may offer some insight into the floristic character of Early Tertiary forests under seasonally wet-dry climates, and may provide evidence on the origins of the modern Australian tropical monsoon plant communities (Greenwood 1994). Initial analyses of these macrofloras suggested that a mosaic of plant communities was reflected in the Middle Eocene Poole Creek palaeochannel sites, with sclerophyllous woodlands (potentially dominated by Eucalyptus spp.) or forests, interspersed with riparian rainforests and possibly also deciduous or partly deciduous 'monsoon forests' (Greenwood et al. 1990, unpub. data). The Poole Creek macrofloras are analysed in greater detail here to determine whether plant communities present in the Eocene included deciduous to partly deciduous 'monsoon forests'.

Theoretical and observational studies in tropical and temperate forests have demonstrated that leaf form, or foliar physiognomy, reflects strongly the local climate (Parkhurst and 
Loucks 1972; Goble-Garrant et al. 1981; Givnish 1984) with, for example, leaf length to width ratio varying along rainfall or temperature (altitude) gradients (Hall and Swaine 1981; Potts and Jackson 1986) and even between understorey and canopy elements (Roth 1984, 1990). In Australian rainforests, for example, mean canopy leaf size is strongly correlated with mean annual temperature (Webb 1968; Greenwood 1992). Previous studies have demonstrated that litter on the forest floor in modern Australian rainforests reflect the foliar physiognomic attributes, or 'foliar physiognomic signature', of the forest canopies (Greenwood 1991, 1992; Christophel and Greenwood 1987, 1989). Other studies have demonstrated similar results in non-rainforest ecosystems (e.g. Burnham 1989; Burnham et al. 1992). Additional samples to those of Greenwood's earlier studies of forest floor litters were collected in modern 'monsoon forests' (Semi-deciduous to Deciduous Vine Forests) in northern Queensland (Fig. 1). These data, together with information derived from litters from subtropical to temperate deciduous to semi-deciduous forests in North America (Greenwood and Basinger 1994, unpub. data; Basinger et al. 1994), are used here to characterise the foliar physiognomic signatures of modern deciduous forests, and tropical deciduous forests (e.g. 'monsoon forests') in particular. Earlier analyses of Early Tertiary Australian leaf macrofloras advanced the argument that matches between modern forest floor litter foliar physiognomic signatures, and those of leaf macrofloras, detect that forest type as being reflected in the fossil assemblage (Greenwood 1992). Greenwood's (1992; Greenwood and Basinger 1994) approach is used here.

\section{Materials and Methods}

\section{Macrofloras}

Considerable data has been amassed on Early Tertiary macrofloras from south-eastern Australia, including analyses of floristic relationships and foliar physiognomic matches with modern rainforests (Christophel 1981; Christophel and Greenwood 1988, 1989; Greenwood 1994). The database being collated by these workers is drawn upon here, together with additional data from central Australian macrofloras. This report concentrates on macrofloras from sites in the vicinity of Lake Eyre, primarily from within the Lake Eyre Basin, and including the Stuart Creek macroflora in the Billa Kalina Basin. Greenwood et al. (1990) recognised a series of Early to mid-Tertiary macrofloras in the present drainage of Poole Creek and Morris Creek as the Poole Creek palaeochannel. Several sites in Eyre Formation in the Poole Creek palaeochannel containing silicified leaf floras, and a single site, Nelly Creek (Eyre Formation), containing a mummified leaf flora, are considered to be correlatives of Middle Eocene macrofloras in the St Vincent's Basin in southern South Australia, and are thus also Middle Eocene (Alley 1989; Christophel et al. 1992; Alley and Sluiter, unpub. data). Additional sites in the Poole Creek palaeochannel are Miocene (Etadunna Formation), and sites in the Stuart Creek area (Willalinchina Sandstone) are likely to be Oligocene (or perhaps Miocene), but may be Eocene (Ambrose et al. 1979). A series of collections from the Early Tertiary Stuart Creek and Poole Creek macrofloras (Greenwood et al. 1990) and from the Nelly Creek macroflora (Christophel et al. 1992) are analysed here. The nomenclature of fossil taxa and informal systematics follows these authors' usage.

The Poole Creek macroflora is a composite of several sites in the silicified sequence of Eyre Formation in the Poole Creek palaeochannel, whereas the Nelly Creek macroflora has been analysed based on a single collection of mummified leaves from the northern (non-silicified) outcrop of Eyre Formation (Greenwood et al. 1990; Christophel et al. 1992). Sample sizes are small in both instances, with the Poole Creek flora (89 leaves versus 171 measured leaves ( $>250$ including fragmented leaves) for Nelly Creek), indicating that the effects of sample-size cannot be ignored (Burnham et al. 1992). Nevertheless, important comparisons can be made between these two samples of Eocene vegetation and modern Australian rainforest and monsoon forest floristics and foliar physiognomy.

\section{Methods of Analysis}

Structural attributes cannot readily be detected in fossil assemblages. However, the foliar physiognomic characteristics, or foliar physiognomic signature, is often reflected in leaf macrofloras that have been sampled quantitatively (Greenwood 1991, 1992). Previous work has demonstrated the utility of modern forest floor leaf litter as a proxy for fossil leaf assemblages for determining the foliar physiognomic signature of plant community types (Christophel and Greenwood 1989). The analysis presented here builds on the earlier physiognomic dataset from modern rainforest leaf litter. Analysis of climate using foliar physiognomy, however, follows the methodology of Wing and Greenwood (1993), based on the CLAMP modern analogue foliar physiognomic and climate data set (Wolfe 1990, 1993). 
Wolfe (1993) demonstrated, in a multivariate analysis (Principal Components) of 106 sites worldwide, strong relationships between key climatic variables and the foliar physiognomic attributes of the woody species at the modern vegetation sites he surveyed. Wing and Greenwood (1993) derived a set of multiple regression equations from Wolfe's (1993) CLAMP dataset from which key climate estimates can be made based on observations of foliar physiognomic attributes of species in a fossil leaf flora. These multiple regression equations were applied to the Eocene Nelly Creek and Poole Creek macrofloras to reconstruct the climate (mean annual temperature, cold month mean, mean annual precipitation and total precipitation of the driest quarter) of the Lake Eyre area in the Middle Eocene (Greenwood and Wing 1995); the results of that analysis are reported more fully here.

Additional data on the foliar physiognomic signatures of modern vegetation, principally deciduous forests in temperate and tropical climates, were amassed by analysing litter samples from sites in North America (Greenwood and Basinger 1994, unpub. data) and a 'monsoon forest-thicket' (40 Mile Scrub) in north Queensland (Fig. 1). The characteristic leaf size spectra and leaf shape characteristics of these deciduous forest litters are contrasted here to those of (evergreen) rainforest litters, and in turn, to Australian Eocene fossil leaf floras representative of rainforest and non-rainforest vegetation.

\section{The Floristic and Foliar Physiognomic Character of Leaf-beds Derived from Modern Australian Monsoon Forests}

\section{Floristics}

Webb and Tracey (1981; Tracey 1982) list a number of woody genera that are either typical of, or characterise, tropical rainforests and monsoonal tropical deciduous vine forests and thickets respectively. In general, all of the vine forests of northern Australia share a large number of species, and at the generic level they group together in ordination analyses (Webb and Tracey 1981; Webb et al. 1986). Key taxa in monsoonal deciduous forests (see Table 1) include: Bombax spp. (Bombaceae), Brachychiton spp. (Sterculiaceae), Cochlospermum spp. (Cochlospermaceae), Gyrocarpus americanus (Hernandiaceae), Flindersia maculosa (Rutaceae), Lysiphyllum cunninghamii (syn. Bauhinia cunninghamii, Caesalpiniaceae), Notelaea microcarpa (Oleaceae), Planchonella cotinifolia (Sapotaceae), and Strychnos lucida (Loganiaceae), amongst others. Species of Brachychiton (e.g. B. acerifolius),

Table 1. Comparison of the common floristic components of selected modern monsoon forest and rainforest sites, and Eocene macrofloras

Data from Tracey (1982) and Greenwood (1994). +, forest typology from Tracey (1982); SDMVF = semi-deciduous, monsoonal vine forest; CNVF = complex notophyll vine forest; DMVT = deciduous, monsoonal vine thicket

\begin{tabular}{|c|c|c|c|c|c|c|c|c|}
\hline \multirow[t]{2}{*}{ Macroflora } & \multicolumn{7}{|c|}{ Site } & \multirow[b]{2}{*}{ Anglesea } \\
\hline & $\begin{array}{c}40 \text { Mile } \\
\text { Scrub }\end{array}$ & $\begin{array}{l}\text { Type } 4 \\
\text { SDMVF }\end{array}$ & $\begin{array}{l}\text { Type } 6 \\
\text { CNVF }\end{array}$ & $\begin{array}{c}\text { Type } 11 \\
\text { DMVT }\end{array}$ & $\begin{array}{l}\text { Nelly } \\
\text { Ck }\end{array}$ & $\begin{array}{l}\text { Poole } \\
\text { Ck }\end{array}$ & $\begin{array}{c}\text { Golden } \\
\text { Grove }\end{array}$ & \\
\hline Agathis & & & + & & + & & & + \\
\hline Brachychiton & + & & + & + & + & + & + & + \\
\hline Bombacaceae & + & + & & + & & & & \\
\hline Gyrocarpus & $?$ & + & & & & & & \\
\hline Ficus & + & + & + & + & & $?$ & & \\
\hline 'legumes' & + & + & + & + & + & + & & + \\
\hline Rutaceae & & + & + & & & & + & + \\
\hline Diospyros & + & + & + & + & $?$ & $?$ & + & + \\
\hline Lauraceae & & & + & & + & $?$ & + & + \\
\hline Elaeocarpaceae & & & + & & & + & + & + \\
\hline Banksieae & & & & & & + & + & + \\
\hline other Proteaceae & + & & + & & + & + & + & + \\
\hline 'Syzygium' & & & + & + & + & + & + & + \\
\hline 'Lophostemon' & & & + & & & + & + & \\
\hline Podocarpus & & + & + & & & & + & + \\
\hline Dacrydium & & & & & + & $?$ & & + \\
\hline
\end{tabular}


Flindersia and Planchonella, may also be common in rainforest. Notable absences or rarities in the tropical deciduous forests and vine thickets include: the conifers Agathis (Araucariaceae) and Podocarpaceae (although conifers may be common in drier rainforest, especially A. robusta, Araucaria spp. and Podocarpus elatus), Lauraceae, and Proteaceae (also prominent in sclerophyllous vegetation). Throughout much of the northern tropics of Australia some genera and species are widespread in evergreen (i.e. rainforest) and deciduous forests, such as Syzygium spp. (Myrtaceae), Ficus spp. (Moraceae), and Diospyros ferrea (various Ebenaceae spp.).

Litter from the 40 Mile Scrub (DMVT) examined for this report was dominated by leaflets of a single species of compound-leaved tree (51-64\% leaves), with a small representation of leaves of emergent species such as Brachychiton australis, and a small to moderate representation of canopy and understorey taxa such as; Notelaea longifolia (Oleaceae), Grevillea sp., and Ficus sp. The dominance of this litter by a single species and the low species richness (only 11 species present between 2 samples, totalling 640 leaves), is in contrast to litter collected in other tropical vine forests in northern Queensland, where typically more than 16 species (range 10-21, mean 16.5) are detected in single litter collections (ca. 200 leaves per sample) with dominants (if present) rarely exceeding $50 \%$ of the leaves in the samples (Greenwood 1992, tables IV, VII-IX and XI).

\section{Foliar Physiognomy}

Monsoonal semi-deciduous to deciduous tropical forests share a number of structural and physiognomic characteristics with rainforests, such as an often prominent liana component, buttressed roots, and a (seasonally) closed canopy (Webb 1959, 1968; Tracey 1982). The canopy in monsoon forests is typically dominated by microphylls to notophylls, although some deciduous species may be mesophyllous (Tracey 1982). Lobed and toothed species, and species with blunt or rounded (versus acute to acuminate) apices are more common in monsoon forests than in rainforests (Wolfe 1993), and leaf size tends to be lower in monsoon forests than in rainforests at similar mean annual temperature (MAT) (Webb 1968). These differences in foliar physiognomy between rainforests and monsoon forests can be expected to be reflected in their forest floor litter (Burnham 1989; Greenwood 1992).

The leaf size spectra (Fig. 2) of the litter samples from deciduous, monsoonal vine forest (DMVT) at the 40 Mile Scrub show a marked dominance by quite small leaves (relative to rainforest litter at similar MAT), as measured by either leaf length (specimens) or leaf area size class (species), with most specimens and all species in the litter being microphylls; significantly, a small number of leaves were detected that were substantially larger than the main population ( $>85 \mathrm{~mm}$ length), and often significantly narrower than the main population. Litter from subtropical deciduous forest in Florida (Fig. 2) similarly shows a dominance by micro-phyllous species (49-54\%), but also a significant presence of much larger leaves (typically representing deciduous species). By contrast, the litter from rainforest at Curtain Fig (CNVF, Atherton Tableland, Qld.) is dominated by notophylls (specimens and species; Fig. 2). The mean leaf length of the 40 Mile Scrub samples ( $36 \mathrm{~mm}$ ) is much lower than would be expected from litter from rainforest at a similar MAT (Table 2), and is much lower than the semi-deciduous forest litter from Florida (68-69 mm mean length).

Of particular interest is the spread of leaf types in the 40 Mile Scrub deciduous forest litter (Fig. 3), with length: width ratios from 1.0 to $>6.0$, with a predominance of species in the narrowly elliptical range (length: width ratio of 2.0-3.0), with a signficant number of specimens in the broad (length: width ratio of about 1.0) and the stenophyllous range (length: width ratio of $>4.0$ ). This pattern is consistent with litters from other deciduous forests (e.g. Florida), and is quite different from that seen in litters from tropical to temperate rainforests (length: width ratio of $>3.0$ dominant; Fig. 3 ). In general, the quite broad leaves in all of the deciduous forest litters represent one or two palmately lobed species (e.g. Brachychiton sp.), and similarly the stenophyllous leaves represent one or two species (e.g. Notelaea longifolia). Quite small leaves in the Florida and 40 Mile Scrub litters generally represented legume leaflets. 
(a) Semi-deciduous broadleaved forest, Gainesville, Forida (USA).

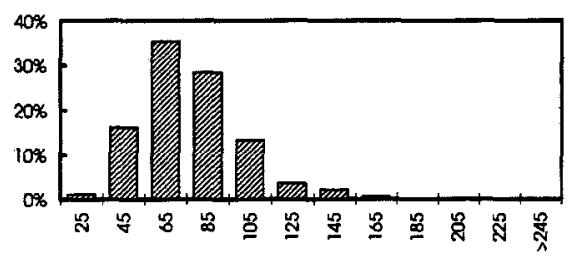

Deciduous Microphyll Vine Forest (monsoon forest), 40 Milie Scrub, NE Old.

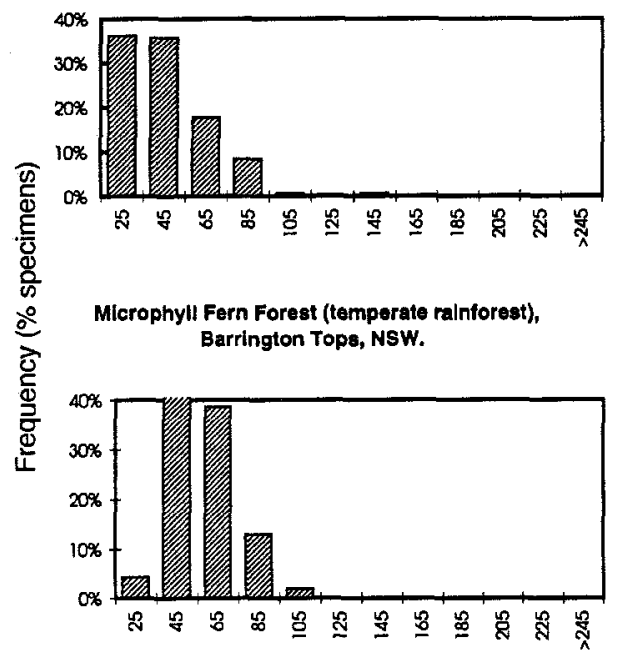

Complex Notophyll Vine Foreat (upland tropical rainforest), Curtain Fig, NE Qli.

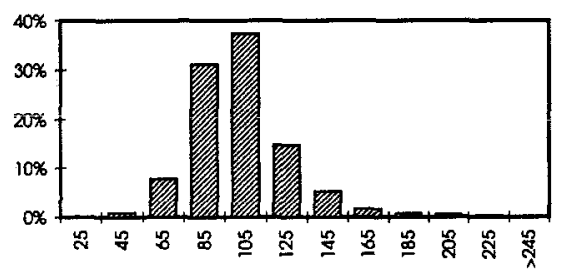

(b) Stuart Creek macroflora, ?Eocene-Ollgocene, northern South Aust.

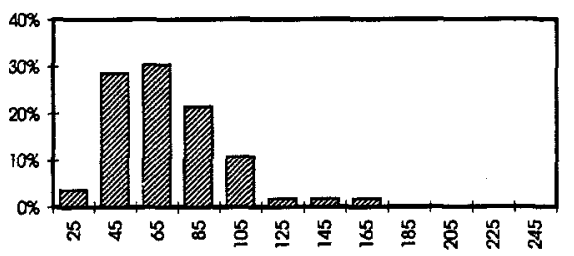

Nelly Ck middle Eocene macrotlora, Lake Eyre Basin, South Aust.

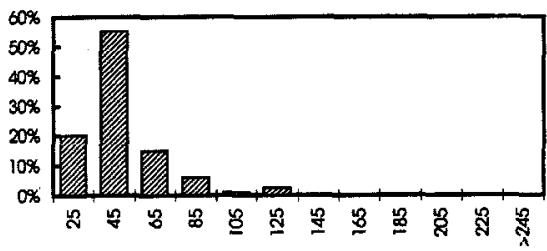

Poole Creek, middle Eocene macroflora, Lake Eyre Basin, South Aust.

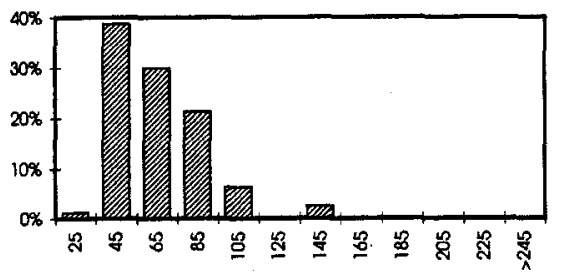

Goiden Grove, middie Eocene macroflora, South Australia.

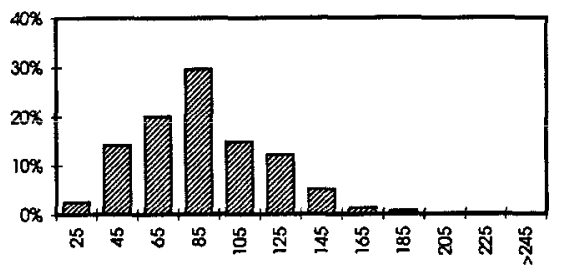

Leaf length (20 $\mathrm{mm}$ classes)

Fig. 2. Leaf size spectra. (a) Samples of litter from modern monsoon forest (DMVT, 40 Mile Scrub), semi-deciduous, subtropical forest (Gainesville, Florida), and rainforest: temperate (MFF, Barrington Tops), and upland tropical rainforest (CNVF, Curtain Fig). (b) Samples from the Stuart Creek, Nelly Creek, and Poole Creek macrofloras (Billa Kalina and Lake Eyre Basins, northern SA), and the Golden Grove macroflora.

\section{Central Australian Eocene Leaf Macrofloras}

\section{Floristic Character}

Floristic analyses of the Nelly Creek and Poole Creek palaeochannel macrofloras are preliminary (e.g. Greenwood et al. 1990, unpub. data; Christophel et al. 1992); nevertheless, important comparisons can be made between these floras and both other Early Tertiary macrofloras, and modern rainforest and tropical-monsoon forest communities (Table 1). The Nelly Creek macroflora contains a number of genera not found today outside the eastern 


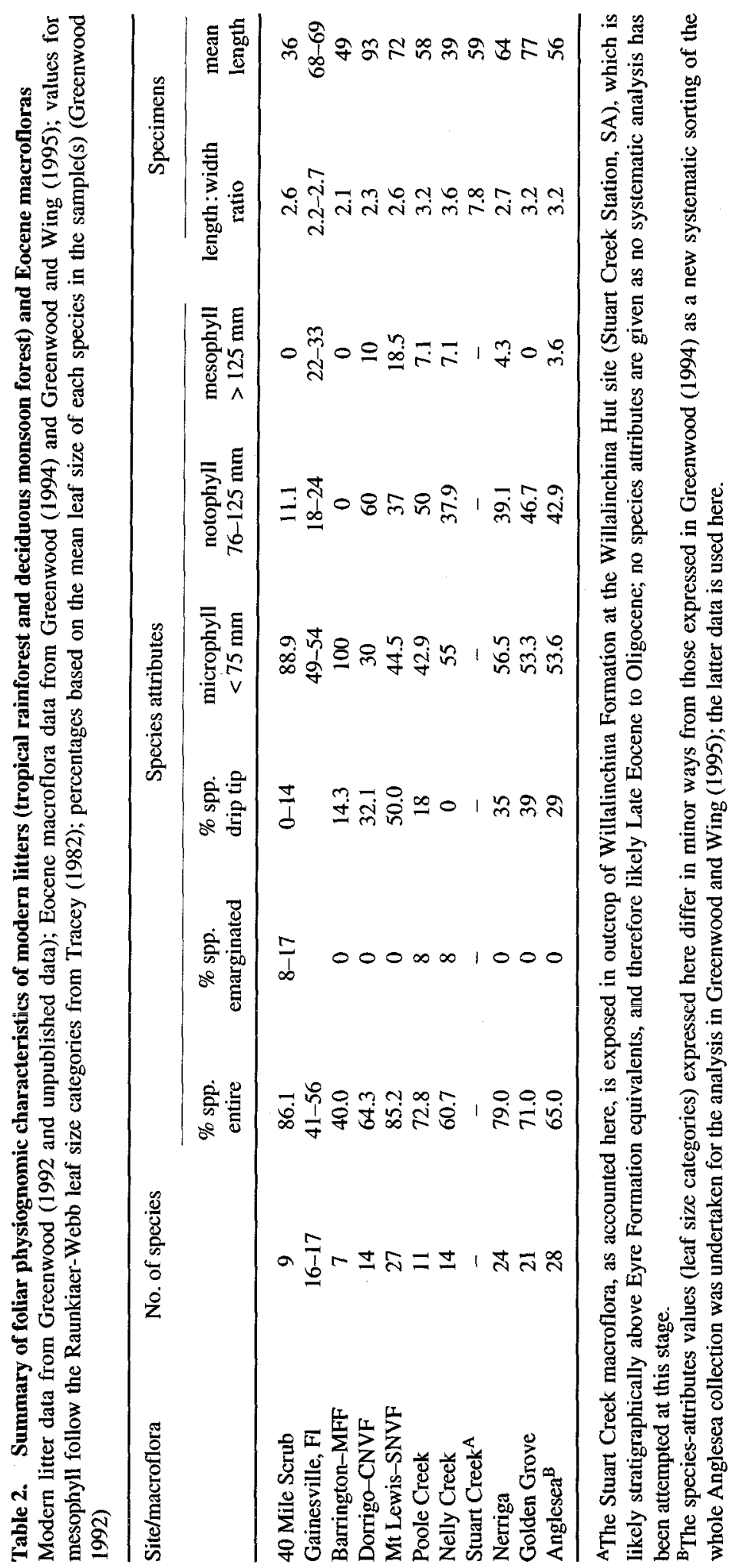


(a)

$$
\text { Modern sclerophyllous woodland, Perth, }
$$
Western Auatralia.

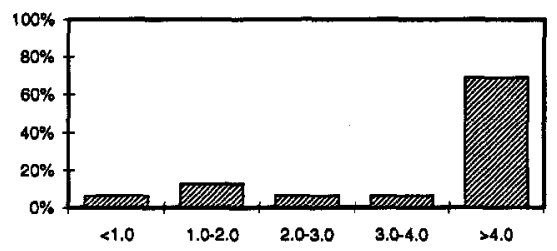

Deciduous Microphyll Vine Forest (monsoon forest), 40 Mile Scrub, NE Old.

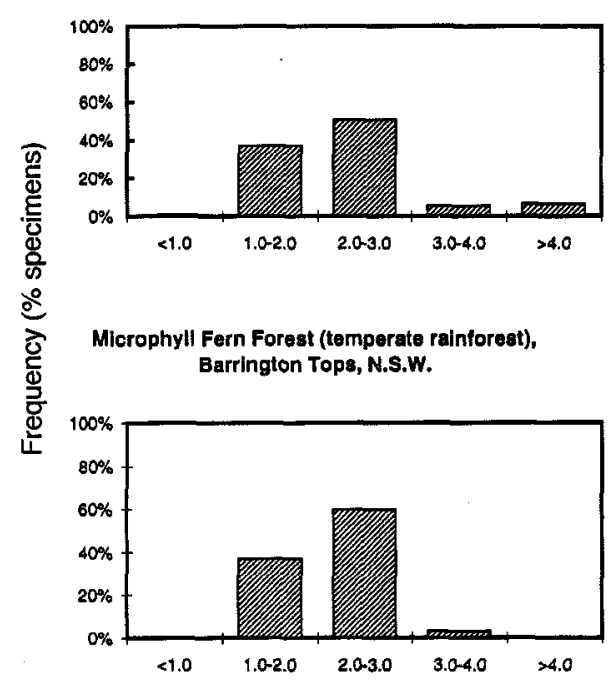

Complex Notophyll Vine Forest (upland tropical rainforest), Curtaln Fig, NE Qld.

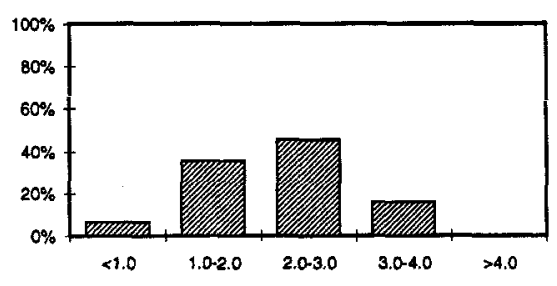

(b)

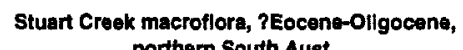
northorn South Aust.

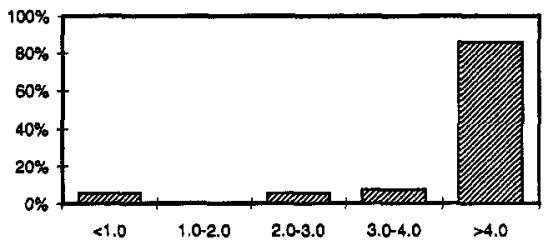

Nelly Ck middle Eocene macroflora, Lake Eyre Basin, South Aust.

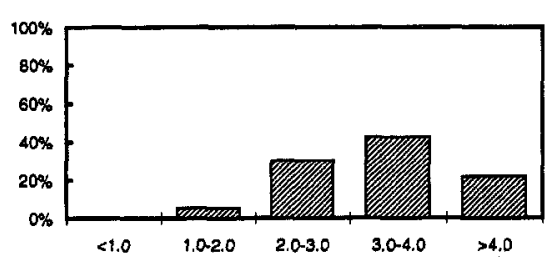

Poole Creek, middie Eocene macroflora, Lake Eyre Basin, South Aust.

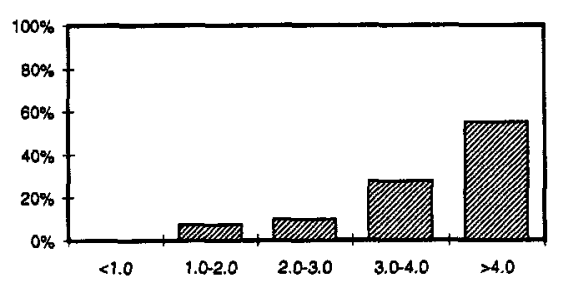

Golden Grove, middle Eocene macroflora, South Australla.

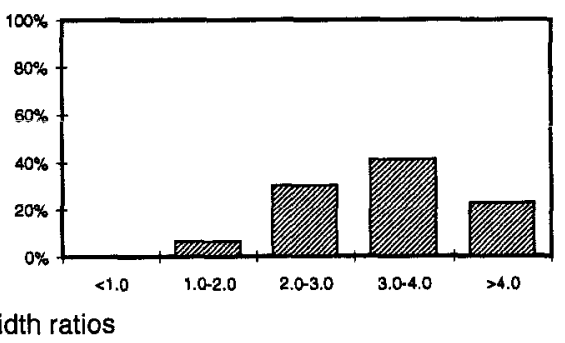

Fig. 3. Leaf length: width ratios of samples examined. (a) Samples of litter from modern sclerophyllous woodland (Perth, WA; from Goble-Garrant et al. 1981), monsoon forest (DMVT, 40 Mile Scrub), and rainforest: temperate (MFF, Barrington Tops), and upland tropical rainforest (CNVF, Curtain Fig). (b) Samples from the Stuart Creek, Nelly Creek, and Poole Creek macrofloras, and the Golden Grove Eocene macroflora.

coastal strip of Australia (or adjacent landmasses), such as the conifers, Agathis and cf. Dacrydium (Podocarpaceae), and foliage of the angiosperm, Gymnostoma (Casuarinaceae). Gymnostoma infructescences are also common in the Poole Creek macroflora (Fig. 4) and occur in other Eyre Formation sites (e.g. Mt Alford). These taxa in modern Australia are commonly regarded as rainforest plants; however, all three may co-occur in seasonally dry swamp forests in Borneo (Brünig 1985; Greenwood 1994), with Dacrydium and Gymnostoma in New Guinea and Fiji as a common component of swamps and forests under 
A

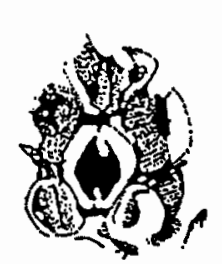

D

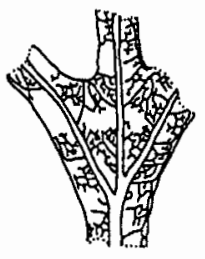

H

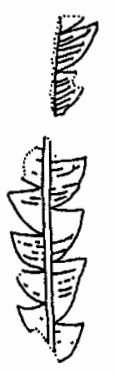

B

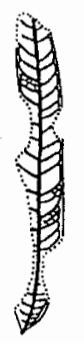

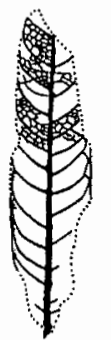

C

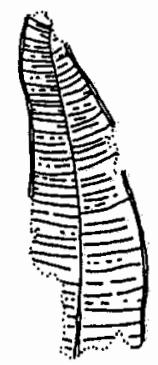

G

$E$

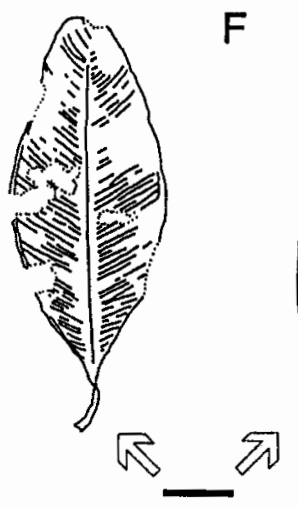

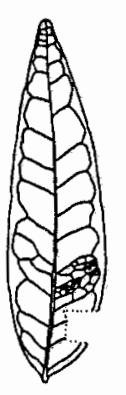

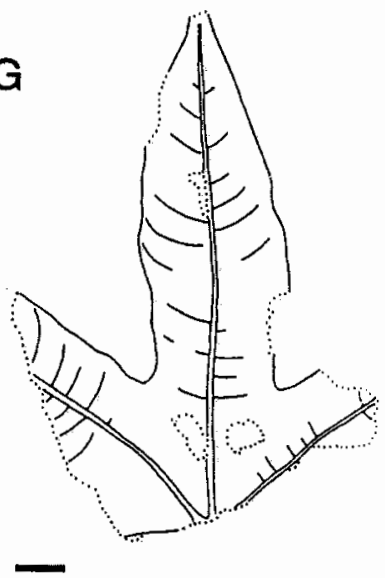

1

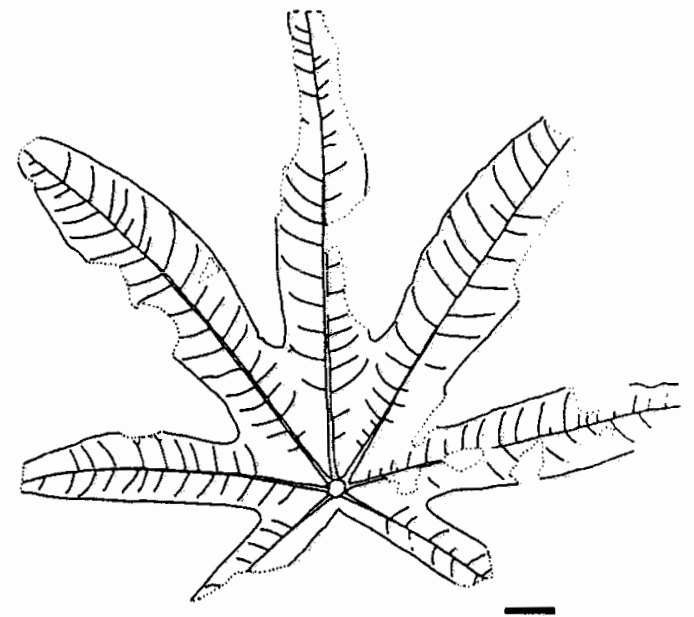

Fig. 4. Examples of leaf and fruit types from the Early Tertiary Nelly Creek, Poole Creek, and Stuart Creek macrofloras. $(A-C)$ Poole Ck: $(A)$ Gymnostoma cone; $(B)$ 'legume' leaflet; $(C)$ stenophyll cf. Apocynaceac. $(D-F)$ Nelly Ck: $(D)$ Proteaceae cf. Grevillea (fragment); (E). Myrtaciphyllum. eremaensis; $(F)$ 'legume' leaflet. $(G-I)$ Stuart Ck.: $(G)$ aff. Brachychiton; $(H)$ Banksieaeformis; $(I) \mathrm{cf}$. Cochlospermum. Scale bars $=1 \mathrm{~cm}$.

mildly seasonal climates (Paijmans 1976; pers. observ.). In Australia, Agathis robusta is commonly found in seasonally moist-dry sites (TDM 100-200 mm) and in NE Queensland may occur as an emergent in dry-season deciduous forests and thickets under moderate rainfall (ca. $1000 \mathrm{~mm}$ year $^{-1}$; Tracey 1982). 
Other taxa present in the Nelly Creek macroflora (e.g. Myrtaciphyllum; Fig. 4) represent modern taxa found in a wide variety of environments, reflecting either imprecise systematic placement of the fossil taxa, and/or wide tolerances of the nearest living relatives (NLRs). Of particular note is the presence of Brachychiton leaves in the Poole Creek and Nelly Creek floras (Fig. 4). Brachychiton today is characteristic of monsoonal deciduous vine thickets and forests across all of tropical Australia (Specht 1981; Webb and Tracey 1981), but also occurs in eastern Australian rainforests (B. discolor, B. acerifolius) and Eucalyptus forests (B. populneus) (Guymer 1988). Taxa such as Banksieaeformis-Banksieaephyllum (Tribe Banksieae, Proteaceae) and cf. Grevillea (Proteaceae) in both Eocene floras (Fig. 4) are consistent with sclerophyllous vegetation (Hill and Christophel 1987), but at the taxonomic resolution presented are not inconsistent with monsoonal vegetarion or rainforest. Some leaf and seed taxa in the Poole Creek flora, however, suggest rainforest (e.g. cf. Athertonia, and Elaeocarpaceae), but are restricted to single sites (Table 3). The common Myrtaceae leaf types in the Poole Creek macroflora fall into three morphotypes: a markedly stenophyllous type suggestive of Eucalyptus, a microphyllous type consistent with Syzygium, and a mesophyllous type similar to Lophostemon. The rare Myrtaceae leaves in the Nelly Creek macroflora (M. eremaensis) are reminiscent of Syzygium. Studies of modern Myrtaceae leaf architecture (Christophel and Lys 1986) indicate that the stenophyll and microphyll Myrtaceae morphotypes may in fact represent extremes of a single taxon; however, these two types are not found associated in the Nelly Creek flora. Fruits of Eucalyptus in association with 'Eucalyptus-type' leaves have been recovered from one site in the Poole Creek palaeochannel, and myrtaceous capsules of non-Eucalyptus-type are known from the Nelly Creek macroflora (Christophel et al. 1992) and so it seems likely that the stenophyllous ('Eucalyptus-type') and ovate-elliptic (cf. Syzygium) myrtaceous leaf-types represent different entities. The dominant type of leaf in the Nelly Creek macroflora is an entiremargined microphyll and is likely to be a leaflet from a compound-leaved species of tree. Similarly, a common leaf type in some sites of the Poole Creek macroflora is also likely to be a leaflet (Fig. 3).

Table 3. Summary of distribution of taxa between sites in the Poole Creek Palaeochannel (Morris and Poole Creeks) and adjacent areas

Data from Greenwood et al. (1990). AOnly a few specimens collected, but taxon was common at site; + , commonly several specimens (3-5) on a single rock sample, number refers to number of rock samples

\begin{tabular}{|c|c|c|c|c|c|c|c|c|c|c|c|}
\hline \multirow[t]{2}{*}{ Taxa } & \multicolumn{3}{|c|}{ Mt Alford } & \multicolumn{3}{|c|}{ Morris Creek } & \multicolumn{5}{|c|}{ Poole Creek } \\
\hline & 1 & 2 & 3 & 4 & 5 & 6 & 7 & 8 & 9 & 10 & 11 \\
\hline Gymnostoma & & 1 & & & & 1 & $10+$ & $5+$ & $12+$ & 1 & 2 \\
\hline Banksieaeformis praegrandis & $1^{A}$ & & & & $2^{\mathrm{A}}$ & 1 & & & & & \\
\hline cf. Dacrydium & & & & 2 & & & & 2. & 1 & 1 & \\
\hline EYR-003 cf. Apocynaceae & 2 & & & 1 & & & & & & & \\
\hline Brachychiton & $1^{A}$ & & & $1^{A}$ & & & & & $1^{\mathrm{A}}$ & & \\
\hline EYR-004 & 2 & & 1 & & 2 & & & & 2 & & \\
\hline EYR-005 'legume' & & & 1 & 1 & 1 & & 7 & 7 & 8 & 1 & \\
\hline EYR-006 & 2 & & 1 & 1 & & & 2 & 2 & & & \\
\hline EYR-007 cf. Orites & & 1 & 1. & & & & & & 2 & & \\
\hline EYR-008 cf: Grevillea & & & & & & 1 & & & & & 2 \\
\hline EYR-009 & & & & & & & $4+$ & $1+$ & & & \\
\hline cf. Elaeocarpus (seed) & & & & & & & & & & & 3 \\
\hline cf. Athertonia (seed) & & & & & & & & & & & 1 \\
\hline 'Lophostemon'. & 2 & & & 2 & 6 & & & & 2 & & \\
\hline Myrtaciphyllum cf: 'Syzygium' & 2 & & 2 & 1 & 1 & & 1. & 4 & 2 & & \\
\hline 'Eucalyptus' leaves & 5 & 3 & 2 & 2 & 5 & 1 & 3 & 1 & 1 & & \\
\hline 'Eucalyptus' fruit. & & & & & & $1+$ & & & & & \\
\hline
\end{tabular}


Christophel et al. (1992) noted the paucity of Lauraceae (one species represented by a single leaf) in the Nelly Creek macroflora, compared with the commonness of Lauraceae leaves in other Eocene macrofloras (e.g. Nerriga, Anglesea and Golden Grove; Hill 1986; Christophel et al. 1987; Christophel and Greenwood 1987). Lauraceae are common components of the canopy and understorey of modern Australian subtropical to tropical rainforests, but are rare to absent in monsoon forests (Tracey 1982), and Whiffin and Hyland (1994) have noted a negative correlation between a high degree of diversity in Lauraceae and seasonal dryness in eastern Australia. Similarly, leaves of Elaeocarpaceae and/or Cunoniaceae (cf. Elaeocarpus, cf. Sloanea) are common in some Eocene 'rainforest' macrofloras, and are common components of modern Australian rainforests (Table 1). Elaeocarpaceae (Elaeocarpus spp.) do occur in drier forest types and in partly deciduous forests in northern Queensland and the Northern Territory. The presence of rare Elaeocarpaceae fruits (Table 4), and leaves cf. Elaeocarpaceae-Cunoniaceae in the Poole Creek macroflora (Greenwood et al. 1990), may therefore reflect either local rainforest patches or drier forest types, possibly including monsoon forest.

Greenwood et al. (1990, unpub. data) examined the occurrence of the principal leaf and seed taxa between Eocene Eyre Formation sites in the Poole Creek palaeochannel (Morris Creek and Poole Creek localities) and in Eyre Formation sites at Mt Alford to the east of Poole Creek (Fig. 1; Table 4). All but 3 of the 11 sites surveyed contained leaves of the 'Eucalyptus-type', with one site at Morris Creek also yielding fruits attributed to Eucalyptus (Table 4). A small leaflet (EYR-005-likely to be representing a legume) and leaves of Myrtaciphyllum (cf. Syzygium) were collected at 7 of the 11 sites. Most taxa were restricted to two or three sites, with some taxa (e.g. cf. Elaeocarpus seed and cf. Athertonia seed) being restricted to a single site. Brachychiton and cf. Dacrydium foliage were found in 3 of the 11 sites, but were negatively associated (Table 4). Some other taxa demonstrated partial negative (e.g. Gymnostoma and Banksieaeformis) or positive associations (e.g. Brachychiton and 'Lophostemon'). Factor Analysis of the occurrence of leaf and fruit taxa between sites in the Poole Creek palaeochannel supports this suggestion of the presence of separate associations of taxa (Greenwood, unpub. data). It is likely that these associations reflect original plant communities in a vegetational mosaic in the Poole Creek palaeochannel catchment.

The Stuart Creek macroflora has not been investigated in any detail, although Lange (1978a, 1982) has reported Eucalyptus fruits and other myrtaceous fruits from this macroflora and stratigraphically related macrofloras near Andamooka. Greenwood $e t$ al. (1990, unpub. data) noted also the presence of Banksieaeformis (2 spp.; Fig. 4), cf. Grevillea, Gymnostoma infructescences, cf. Eucalyptus leaves and other Myrtaceae leaves, Brachychiton leaves (?2 spp.; Fig. 4) and commented that a much greater diversity of leaf forms was likely to be present in this flora than in the Poole Creek macroflora. Some of the putative Brachychiton leaves from Stuart Creek are 5- or 7-lobed (Fig. 4) with leaf architecture matching closely that of Cochlospermum fraseri (Cochlospermaceae), the kapok, a common deciduous tree in monsoon vine thickets in northern Australia; and so some specimens may represent Cochlospermum rather than Brachychiton. There are floristic similarities between the Stuart Creek macroflora and those of the Middle Eocene sites of the Poole Creek palaeochannel (Greenwood et al. 1990, unpub. data; Christophel et al. 1992), including some fossil species in common (e.g. Banksieaeformis praegrandis); however, there are important foliar physiognomic differences between the Stuart Creek and the Poole Creek palaeochannel floras.

\section{Foliar Physiognomic Signatures}

The Poole Creek, Nelly Creek, and the Stuart Creek floras are all dominated by small $(63-70 \%<65 \mathrm{~mm}$ length) entire-margined narrow elliptic to stenophyllous leaves $(55-86 \%$ of leaves with a length: width ratio of $>3.0$ ). The leaf size spectra for all three of the floras show a skewed normal distribution (Fig. 2), with modes of $26-45 \mathrm{~mm}$ (Nelly and Poole Creeks) and 46-65 $\mathrm{mm}$ (Stuart Creek) respectively, and the presence of a small but significant set of leaves much larger than the main population of leaves $(9-17 \%>85 \mathrm{~mm}$ 
length). The Stuart Creek flora, however, has larger leaves than recorded for the Nelly Creek flora (mean leaf lengths $59.2 \mathrm{~mm}$ and $38.9 \mathrm{~mm}$ respectively-the Poole Creek value cannot be considered reliable due to the small sample size); however, a significant taphonomic collection bias is likely to exist in the Nelly Creek flora as numerous fragments in the collection and field observations indicate the presence of notophyll to mesophyll taxa. The range of leaf shapes in the Poole Creek and Nelly Creek floras (Figs 3,4) shows discrete sets of leaf types (generally represented by one or two species only), with most in the 3.0-4.0 to $>4.0$ length: width ratio band (Fig. 4), but with significant representatives of quite wide leaves (Brachychiton length: width ratio ca. 1.0) and quite stenophyllous leaves (e.g. 'eucalypt-type' and Banksieaeformis sp. 2, both length: width ratio > 6.0). Lobed leaf types were not uncommon in all three floras (Fig. 4), with one or two species of Brachychiton (3-7 lobes), and two or three lobed species of Proteaceae; toothed leaves and species were scarce with less than 5\% of specimens and only one or two species having toothed leaf margins. The Stuart Creek flora, however, is strongly characterised by markedly stenophyllous leaves (> 69\%, length: width ratio $>6.0$ ), especially when compared with either modern rainforest or other Eocene macrofloras (e.g. Golden Grove, 95\%, length: width ratio $<6.0$ ), including the Poole Creek $(66 \%$, length: width ratio $<6.0)$ and Nelly Creek floras $(93 \%$, length: width ratio $<6.0$ ); this dominance by stenophylls is reflected in the leaf length: width spectra (Fig. 4) and the mean length:width ratio of these floras (Table 2), with modern rainforest litter typically showing a peak in the 2.0-3.0 length: width ratio range, and with a mean length: width ratio ranging from 2.3 to 3.4 , compared with a peak $>4.0$ and a mean of 7.8 for Stuart Creek. Poole Creek is similarly characterised by stenophyllous leaves (peak also at $>$ 4.0 length: width ratio), but not to the same extent as Stuart Creek (e.g. Poole Creek mean length: width ratio 3.2 ).

\section{Central Australian Eocene Environments}

The taxa represented in the Nelly Creek and Poole Creek macrofloras provide only equivocal climatic or palaeoecological information (Greenwood and Wing 1995, and discussion above). All of the identified genera are consistent with a forested environment in central Australia in the Eocene. Scarce epiphyllous microfungal germlings (Lange 1978b) found during a survey of cuticle from Nelly Creek leaves (Christophel et al. 1992) indicate a mean annual precipitation of less than $1200 \mathrm{~mm}$. Today Agathis is relict in its distribution and so palaeoenvironmental inference based on this taxon must be considered in that light. Agathis in Australia is found in rainforests under Mesothermal-Megathermal climates (MAT $>18^{\circ} \mathrm{C}$ ), often with a distinct dry season (e.g. in Type $6 \mathrm{CNVF}$; Tracey 1982; driest quarter ca.100-200 mm, Kershaw and Nix 1988), but equally so, in Mesothermal climates that are not seasonally dry (e.g. New Zealand, at MAT $>14^{\circ} \mathrm{C}$; Mitchell 1990). Similarly, Brachychiton is today found in seasonally dry, frost-free Mesothermal-Megathermal climates in Australia (Guymer 1988). Eucalyptus sensu stricto fruits have been identified in the Stuart Creek macroflora (Lange 1978a, 1982), and leaves likely to be representing Eucalyptus are found in the Poole Creek palaeochannel flora (Morris Creek site); however, given the wide thermal range and both seasonal and annual variation of rainfall seen throughout the range of Eucalyptus, it is only possible to suggest seasonal drought (or mean annual precipitation (MAP) $<1200 \mathrm{~mm}$ ) and/or low soil fertility for the Lake Eyre region in the Eocene to Oligocene. Some other taxa present support the interpretation of a Mesothermal-Megathermal climate (e.g. Gymnostoma) and are consistent with essentially frost-free conditions, while the presence of Banksieaeformis species may also reflect seasonal drought/MAP $<1000 \mathrm{~mm}$, and/or low soil fertility. Some taxa contradict indicators of lower MAP or seasonal drought (e.g. cf. Dacrydium, Gymnostoma, cf. Lophostemon), but may reflect local swamp or riparian components.

Using the CLAMP-derived multiple regression equations (Wolfe 1990 1993; Wing and Greenwood 1993) a MAT of $18.7-21.1^{\circ} \mathrm{C}\left( \pm 2^{\circ} \mathrm{C}\right)$ was estimated for the area of southern Lake Eyre in the Middle Eocene (Greenwood and Wing 1995). This estimate is consistent with estimates for other Eocene floras at similar latitudes (Table 4), and at higher latitudes (assuming a latitudinal gradient of $0.3-0.4^{\circ} \mathrm{C} / 1^{\circ}$ latitude), but the estimate for Poole Creek 
Table 4. Climate statistics for modern Australian sub-tropical to tropical stations, and multiple regression estimates for Eocene macrofloras

Based in part on Gentilli (1971), Greenwood (1992, 1994), Wing and Greenwood (1993) and Greenwood and Wing (1995). MAT, mean annual temperature, s.e. $2.0^{\circ} \mathrm{C}, r^{2} 0.86$; CMM, coldest month mean $\mathrm{T}^{\circ}$, s.e. $3.6^{\circ} \mathrm{C}, r^{2} 0.76$; MAP, mean annual precipitation, s.e. $580 \mathrm{~mm}, r^{2} 0.5$; TDM, three driest months precip., s.e. $90 \mathrm{~mm}, r^{2} 0.55$; TGSP, total 'growing season' precipitation, s.e. $470 \mathrm{~mm}, r^{2}$ 0.58. (s.e., standard error of the estimate; $r^{2}$, multiple regression: see Wing and Greenwood 1993); DMVT $=$ deciduous monsoonal vine thicket $; \mathrm{CNVF}=$ complex notophyll vine forest; SNVF $=$ simple notophyll vine forest

\begin{tabular}{|c|c|c|c|c|c|c|}
\hline Site and forest type & $\begin{array}{l}\text { latitude and altitude } \\
\text { (modern) }\end{array}$ & $\stackrel{\mathrm{MAT}}{{ }^{\circ} \mathrm{C}}$ & $\underset{{ }^{\circ} \mathrm{C}}{\mathrm{CMM}}$ & $\begin{array}{c}\text { MAP } \\
\text { mm } \\
\text { year-1 }^{-1}\end{array}$ & $\begin{array}{c}\text { TDM } \\
\text { mm } \\
\text { quarter-1 }\end{array}$ & $\begin{array}{c}\text { TGSP } \\
\text { mm } \\
\text { quarter-1 }^{-1}\end{array}$ \\
\hline 40 Mile Scrub-DMVT ${ }^{A}$ & $18^{\circ} 04^{\prime} \mathrm{S}, 700 \mathrm{~m}$ & 22.6 & 15.6 & 914 & 18 & 653 \\
\hline Mt Surprise-DMVT & $18^{\circ} 09^{\prime} \mathrm{S}, 453 \mathrm{~m}$ & 23.9 & 18.2 & 799 & 18 & 535 \\
\hline Dorrigo ${ }^{\mathrm{A}}-\mathrm{CNVF}$ & $30^{\circ} 20^{\prime} \mathrm{S}, 100 \mathrm{~m}$ & 18.4 & 12.6 & 1759 & 238 & 716 \\
\hline Curtain Fig-CNVFA & $17^{\circ} 18^{\prime} \mathrm{S}, 720 \mathrm{~m}$ & 20.0 & 15.7 & 1425 & 75 & 860 \\
\hline Farina (Lake Eyre) & $29^{\circ} 30^{\prime} \mathrm{S}, 50 \mathrm{~m}$ & 19.7 & 10.7 & 146 & 24 & 70 \\
\hline Poole Creek & $29^{\circ} 30^{\prime} \mathrm{S}, 50 \mathrm{~m}$ & 21.1 & 12.5 & 1110 & 60 & 770 \\
\hline Nelly Creek & $29^{\circ} 19^{\prime} \mathrm{S}, 5 \mathrm{~m}$ & 18.9 & 14.7 & 1360 & 100 & 760 \\
\hline Golden Grove-CNVF & $34^{\circ} 47^{\prime} \mathrm{S}, 120 \mathrm{~m}$ & 18.7 & 10.2 & 1910 & 290 & 950 \\
\hline Anglesea-SNVF & $38^{\circ} 25^{\prime} \mathrm{S}, 50 \mathrm{~m}$ & 17.1 & 8.2 & 2220 & 240 & 1400 \\
\hline
\end{tabular}

A40 Mile Scrub values are taken from Mareeba $\left(17^{\circ} 00^{\prime} \mathrm{S}, 404 \mathrm{~m}\right)$, with MAT and CMM adjusted $\left(\downarrow 2.7^{\circ} \mathrm{C}\right)$ assuming an altitudinal lapse rate of $0.7^{\circ} \mathrm{C}, 100 \mathrm{~m}$ and a latitudinal thermal gradient of $0.6^{\circ} \mathrm{C} / 1^{\circ}$ latitude; Dorrigo values are taken from Coffs Harbour $\left(30^{\circ} 19^{\prime} \mathrm{S} \mathrm{m}\right)$; Curtain Fig values represent a composite of Atherton (ppt.) and Kairi Experimental Station $\left(\mathrm{T}^{\circ}\right)$ records

$\left(21.1^{\circ} \mathrm{C}\right)$ is slightly higher than estimates derived from NLR analogy based on Eyre Formation microfloras for sites nearby (Sluiter 1991); however, this discrepancy may reflect uncertainties in the multiple regression estimate for Poole Creek rather than any real differrence (Greenwood et al., unpub. data). The estimates for winter temperature using multiple regression estimates $\left(\mathrm{CMM} 12.5-14.7^{\circ} \mathrm{C}\right)$ indicate essentially frost-free climates for the Lake Eyre region in the Middle Eocene, and are similar to present values in the Lake Eyre region (e.g. Farina, Table 4). Significantly, the multiple regression estimates for MAP (1110-1360 mm $\pm 580 \mathrm{~mm}$ ), TDM ('driest quarter' $0-100 \mathrm{~mm}^{\prime}$ quarter ${ }^{-1} \pm 90 \mathrm{~mm}$ ) and TGSP ('growing season' $760 \mathrm{~mm}$ quarter ${ }^{-1}$ ), indicate a seasonally dry climate with a moderate to high annual rainfall. Unfortunately, the present methodology does not allow discrimination between a summer or winter dry season; although the estimate for the growing season (TGSP) suggests a summer rainfall-peak as at the higher latitudes of central Australia in the Eocene (ca. $12-15^{\circ}$ further south) suggesting a summer growing season is likely. Overall, however, the estimates of MAT, CMM, MAP, TDM and TGSP are consistent with a monsoon climate, and are similar to that of the modern monsoon forest site (40 Mile Scrub, Table 2) used in the analysis. The multiple regression estimates are also consistent with the consensus NLR interpretation of moderate annual rainfall (MAP ca. $1000 \mathrm{~mm}$ ) and a dry season (but no seasonal drought), but at the lower ends of the estimates suggest a drier more seasonal climate than is supported by the NLR's, or by sedimentological evidence (Quilty 1984; Wells and Callen 1986; Greenwood et al., unpub. data).

\section{Conclusions}

This analysis cannot conclusively identify whether Eocene forests in central Australia grew under a monsoonal climate, and on some grounds appears to suggest that the climate was not monsoonal and that deciduous 'monsoon forest' was not present. That the climate, reflected in the Poole Creek and Nelly Creek Eocene macrofloras and the ?EoceneOligocene Stuart Creek macroflora, was seasonally dry (TDM $<150 \mathrm{~mm}$ ) and of moderate 
annual rainfall (MAP ca. $1000 \mathrm{~mm}$ ), is clear. The thermal regime, using Nix's (1982) classification, would be Mesothermal-Megathermal in each instance. The floristic mix in the Eocene floras is consistent (in most respects), based on limited information, with tropical seasonally dry 'rainforests' (Type 6 in Tracey's (1982) typology) in NE Qld, but differs markedly from these modern forests in the presence of needle-leaved Podocarpaceae (cf. Dacrydium) and Gymnostoma, and from more inland modern monsoon communities in the presence of Agathis, Elaeocarpaceae and Lauraceae. Similar floristic mixes do occur, however, under tropical monsoon climates in modern Borneo. The foliar physiognomic signatures of the central Australian Eocene vegetation is, however, intermediate between modern monsoon forest litters and rainforest litters, lending some credence to the notion that monsoonal forest communities may have occurred in central Australia in the Eocene, whereas the ?Eocene-Oligocene Stuart Creek macroflora appears to reflect sclerophyllous vegetation (e.g. Lange 1982; Truswell 1990). No distinctive floristic elements of monsoon forest (other than Brachychiton and a prominent ?legume component) have been identified in these macrofloras; rather, elements found today in rainforest (Agathis, cf. Athertonia) and sclerophyllous vegetation (e.g. Banksieaeformis, 'Eucalyptus') appear to be prominent (but not dominant). The possibility remains, however, that distinctive monsoon forest elements (e.g. Bombax, Cochlospermum, Gyrocarpus) may yet be identified in these macrofloras as associated microfloras contain palynomorphs attributed to some of these taxa (Martin 1978; Kemp 1981; Truswell and Harris 1982; Truswell et al. 1987).

\section{Acknowledgments}

This research was initiated during a research project on the biostratigraphy and palaeoenvironments of the Lake Eyre Basin 'silcrete floras' funded by the Department of Mines and Energy, South Australia. Subsequent analyses of Eocene floras and modern litter samples benefitted from access to materials and facilities during a Postdoctoral Fellowship at the (US) National Museum of Natural History of the Smithsonian Institution (Washington, DC). Modern litter samples from 40 Mile Scrub were collected by D. C. Christophel, and samples from Florida were collected and analysed by the author with the assistance of C. L. Greenwood, D. L. Dilcher (Florida Museum of Natural History, Gainesville) and C. Dilcher. I would also like to note the valuable discussions with S. L. Wing, D. L. Dilcher, K. J. Johnson, N. F. Alley, J. A. Wolfe, J. F. Basinger and D. C. Christophel. Additional data on New Guinea forests (1984) and Fijian vegetation (1989-1990) were collected during fieldwork funded by the Holtze Fund (University of Adelaide) and the University of the South Pacific respectively, the latter during tenure as the Curator of the South Pacific Regional Herbarium.

\section{References}

Alley, N. F. (1987). Middle Eocene age of the megafossil flora at Golden Grove, South Australia: preliminary report, and comparison with the Maslin Bay Flora. Transactions of the Royal Society of South Australia 111, 211-212.

Alley, N. F., Krieg, G. W., and Callen, R. A. (1996). Early Tertiary Eyre Formation, lower Nelly Creek, southern Lake Eyre Basin, Australia: palynological dating of macrofloras and silcrete, and palaeoclimatic implications. Australian Journal of Earth Sciences 43, 71-84.

Ambrose, G. J., Callen, R. A., Flint, R. B., and Lange, R. T. (1979). Eucalyptus fruits in stratigraphic context in Australia. Nature 280, 387-389.

Basinger, J. F., Greenwood, D. R., and Sweda, T. (1994). Early Tertiary vegetation of Arctic Canada and its relevance to palaeoclimatic interpretation. In 'Cenozoic Plants and Climates of the Arctic'. (Eds M. C. Boulter and H. C. Fisher.) pp. 175-198. (Springer-Verlag: Berlin.)

Beard, J. S. (1944). Climax vegetation in tropical America. Ecology 25, 127-158.

Blackburn, D. T. (1981). Tertiary megafossil flora of Maslin Bay, South Australia: numerical taxonomic study of selected leaves. Alcheringa 5, 9-28.

Brüig, E. F. (1985). Vegetation structure and growth. In 'Tropical Forest Ecosystems: Structure and Function'. (Ed. F. B. Golley.) pp. 49-76. (Elsevier: Amsterdam.)

Burnham, R. J. (1989). Relationships between standing vegetation and leaf litter in a paratropical forest: implications for paleobotany. Review of Palaeobotany and Palynology 58, 5-32. 
Burnham, R. J., Wing, S. L., and Parker, G. G. (1992). The reflection of deciduous forest communities in leaf litter: implications for autochthonous litter assemblages from the fossil record. Paleobiology $18,30-49$.

Christophel, D. C. (1981). Tertiary megafossil floras as indicators of floristic associations and palaeoclimate. In 'Ecological Biogeography of Australia'. (Ed. A. Keast.) pp. 379-390. (Junk: The Hague.)

Christophel, D. C. (1988). Evolution of the Australian flora through the Tertiary. Plant Systematics and Evolution 162, 63-78.

Christophel, D. C., and Greenwood, D. R. (1987). A megafossil flora from the Eocene of Golden Grove, South Australia. Transactions of the Royal Society of South Australia 111, 155-162.

Christophel, D. C., and Greenwood, D. R. (1988). A comparison of Australian tropical rainforest and Tertiary fossil leaf-beds. In 'The Ecology of Australia's Wet Tropics'. (Ed. R. Kitching.) pp. 139-148. (Surrey Beatty and Sons: Chipping Norton, NSW.)

Christophel, D. C., and Greenwood, D. R. (1989). Changes in climate and vegetation in Australia during the Tertiary. Review of Palaeobotany and Palynology 58, 95-109.

Christophel, D. C., and Lys, S. D. (1986). Mummified leaves of two new species of Myrtaceae from the Eocene of Victoria, Australia. Australian Journal of Botany 34, 649-662.

Christophel, D. C., Harris, W. K., and Syber, A. K. (1987). The Eocene flora of the Anglesea locality, Victoria. Alcheringa 11, 303-323.

Christophel, D. C., Scriven, L. J., and Greenwood, D. R. (1992). The Middle Eocene megafossil flora of Nelly Creek (Eyre Formation), Southern Lake Eyre Basin, South Australia. Transactions of the Royal Society of South Australia 116, 65-76.

Crisp, M. D., Linder, H. P., and Weston, P. H. (1995). Cladistic biogeography of plants in Australia and New Guinea: congruent pattern reveals two endemic tropical tracks. Systematic Biology 44, $457-473$.

Gentilli, J. (1971). Climates of Australia and New Zealand. In 'World Survey of Climatology, Vol. 13'. (Elsevier: Amsterdam.)

Givnish, T. J. (1984). Leaf and canopy adaptations in tropical forests. In 'Physiological Ecology of Plants of the Wet Tropics'. (Eds E. Medina and C. Vazquez-Yanes.) pp. 51-84, (Junk: The Hague.)

Goble-Garrant, E. M., Bell, D. T., and Loneragan, W. A. (1981). Floristic and leaf structure patterns along a shallow elevational gradient. Australian Joumal of Botany 29, 329-347.

Greenwood, D. R. (1988). The foliar physiognomic analysis and taphonomy of leaf-beds derived from modern Australian rainforest. $\mathrm{PhD}$ Thesis, University of Adelaide.

Greenwood, D. R. (1991). The taphonomy of plant macrofossils. In 'Fossilization: the Processes of Taphonomy'. (Ed. S. K. Donovan.) pp. 145-169. (Belhaven Press: London.)

Greenwood, D. R. (1992). Taphonomic constraints on foliar physiognomic interpretations of Late Cretaceous and Tertiary palaeoclimates. Review of Palaeobotany and Palynology 71, 142-194.

Greenwood, D. R. (1994). Palaeobotanical evidence for Australian tertiary climates. In 'History of the Australian Vegetation. Cretaceous to Recent'. (Ed. R. S. Hill.) pp. 44-59. (Cambridge University Press: Cambridge.)

Greenwood, D. R., and Basinger, J. F. (1994). The paleoecology of high latitude Eocene swamp forests from Axel Heiberg Island, Canadian High Arctic. Review of Palaeobotany and Palynology 81, 83-97.

Greenwood, D. R., and Wing, S. L. (1995). Eocene continental climates and latitudinal gradients. Geology 23, 1040-1048.

Greenwood, D. R., Callen, R. A., and Alley, N. F. (1990). The correlation and depositional environment of Tertiary strata based on macrofloras in the Southern Lake Eyre Basin. South Australian Department of Mines and Energy, Report Book No. 90/15, Adelaide.

Guymer, G. P. (1988). A taxonomic revison of Brachychiton (Sterculiaceae). Australian Systematic Botany 1, 199-323.

Hall, J. B., and Swaine, M. D. (1981). 'Distribution and Ecology of Vascular Plants in a Tropical Rainforest Vegetation in Ghana. Geobotany 1.' (Junk: The Hague.)

Hill, R. S. (1986). Lauraceous leaves from the Eocene of Nerriga, New South Wales. Alcheringa 10, $327-351$.

Hill, R. S. (1992). Australian vegetation during the Tertiary: macrofossil evidence. The Beagle, Records of the Northern Territory Museum of Arts and Sciences 9, 1-10.

Hill, R. S., and Bigwood, A. J. (1987). Tertiary gymnosperms from Tasmania: Araucariaceae. Alcheringa 11, 325-335.

Hill, R. S., and Christophel, D. C. (1987). Tertiary leaves of the tribe Banksieae (Proteaceae) from south-eastern Australia. Botanical Journal of the Linnean Society 97, 205-227. 
Hill, R. S., and Merrifield, H. E. (1993). An Early Tertiary macroflora from West Dale, southwestern Australia. Alcheringa 17, 285-326.

Holdridge, L. R. (1967). 'Life Zone Ecology.' (Tropical Science Center: San Jose, Costa Rica.)

Kemp, E. M. (1978). Tertiary climatic evolution and vegetation history in the southeast Indian Ocean region. Palaeogeography, Palaeoclimatology, Palaeoecology 24, 169-208.

Kemp, E. M. 1981. Tertiary palaeogeography and the evolution of Australian climate. In 'Ecological Biogeography of Australia'. (Ed. A. Keast.) pp. 31-50. (Junk: The Hague.)

Kershaw, A. P., and Nix, H. A. (1988). Quantitative palaeoclimatic estimates from pollen data using bioclimatic profiles of extant taxa. Journal of Biogeography 15, 589-602.

Lange, R. T. (1978a). Southern Australian Tertiary epiphyllous fungi, modern equivalents in the Australasian region, and habitat indicator value. Canadian Journal of Botany 56, 532-541.

Lange, R. T. (1978b). Carpological evidence for fossil Eucalyptus and other Leptospermeae (subfamily Leptospermoideae of Myrtaceae) from a Tertiary deposit in the South Australian arid zone. Australian Journal of Botany 26, 221-233.

Lange, R. T. (1982). Australian Tertiary vegetation, evidence and interpretation. In 'A History of Australasian Vegetation'. (Ed. J. M. G. Smith.) pp. 44-89. (McGraw Hill: Sydney.)

Martin, H. A. (1978). Evolution of the Australian flora and vegetation through the Tertiary: evidence from pollen. Alcheringa 2, 181-202.

Martin, H. A. (1982). Changing Cenozoic barriers and the Australian palaeobotanical record. Annals of the Missouri Botanical Gardens 69, 625-667.

Martin, H. A. (1990). The palynology of the Namba Formation in the Wooltana-1 bore, Callabona Basin (Lake Frome), South Australia, and its relevance to Miocene grasslands in central Australia. Alcheringa 14, 247-255.

Martin, H. A. (1993). The palaeovegetation of the Murray Basin, Late Eocene to Mid-Miocene. Australian Systematic Botany 6, 491-531.

Mitchell, N. D. (1990). The deriviation of climate surfaces for New Zealand, and their application to the bioclimatic analysis of the distribution of kauri (Agathis australis). Journal of the Royal Society of New Zealand 21, 25-32.

Nix, H. (1982). Environmental determinants of biogeography and evolution in Terra Australis. In 'Evolution of the Flora and Fauna of Arid Australia. Ch. 5'. (Eds W. R. Barker and P. J. M. Greenslade.) pp. 47-66. (Peacock Publications: Adelaide.)

Paijmans, K. (1976). 'New Guinea Vegetation.' (CSIRO and Australian National University Press: Canberra.)

Parkhurst, D. F., and Loucks, D. L. (1972). Optimal leaf size in relation to environment. Journal of Ecology 60, 505-537.

Pole, M., and Bowman, D. M. (1994). Tertiary plant fossils from Melville Island, Northern Territory. In 'Origin and Evolution of the Flora of the Monsoon Tropics'. (Eds J. Clarkson, J. Neldner, B. Waterhouse, E. Brown, B. Jackes and B. P. M. Hyland.) p. 27. (Australia Systematic Botany Society: Canberra.)

Potts, B. M., and Jackson, W. D. (1986). Evolutionary processes in the Tasmanian high altitude eucalypts. In 'Flora and Fauna of Alpine Australia'. (Ed. B. A. Barlow.) pp. 511-528. (CSIRO/ Australian Systematic Botany Society: Melbourne.)

Quilty, P. G. (1984). Mesozoic and Cenozoic history of Australia as it affects the Australian biota. In 'Arid Australia'. (Eds H. G. Cogger and E. E. Cameron.) pp. 7-56. (Australian Museum: Sydney.)

Richards, P. W. (1952). The Tropical Rainforest: An Ecological Study. (Cambridge University Press: .)

Roth, I. (1984). 'Stratification in Tropical Forests as Seen in Leaf Structure. Tasks for Vegetation Science 6.' (Junk: The Hague.)

Roth, I. (1990). Leaf structure of a Venezuelan cloud forest (in relation to the microclimate). In 'Encyclopedia of Plant Anatomy 14(1)'. (Gerbrüder Borntraeger: Berlin.)

Sluiter, I. R. K. (1991). Early Tertiary vegetation and climates, Lake Eyre region, northeastern South Australia. In 'The Cainozoic in Australia: a Re-appraisal of the Evidence'. (Eds M. A. J. Williams, P. DeDeckker and A. P. Kershaw.) pp. 99-118. (Geological Society of Australia: Sydney.)

Specht, R. L. (1981). Major vegetation formations in Australia. In 'Ecological Biogeography of Australia, Vol. 1'. (Ed. A. Keast.) pp. 163-298. (Junk: The Hague.)

Tracey, J. G. (1982). The Vegetation of the Humid Tropics of North Queensland. (CSIRO: Melbourne.)

Truswell, E. M. (1990). Australian rainforests: the 100 million year record. In 'Australian Tropical Rainforests'. (Eds L. J. Webb and J, Kikkawa.) pp. 7-22. (CSIRO: Melbourne.)

Truswell, E. M., and Harris, W. K. (1982). The Cainozoic palaeobotanical record in arid Australia: fossil evidence for the origin of an arid-adapted flora. In 'Evolution of the Flora and Fauna of Arid Australia'. (Eds W. R Barker and P. J. M. Greenslade.) pp. 67-76. (Peacock Publications: Adelaide.) 
Truswell, E. M., Kershaw, A. P., and Sluiter, I. R. (1987). The Australian-South-East Asian connection: evidence from the palaeobotanical record. In 'Biogeographical Evolution of the Malay Archipelago'. (Ed. T. C. Whitmore.) pp. 32-49. (Oxford University Press: Oxford.)

Webb, L. J. (1959). A physiognomic classification of Australian rainforests. Journal of Ecology 47, 551-570.

Webb, L. J. (1968). Environmental determinants of the structural types of Australian rain forest vegetation. Ecology 49, 296-311.

Webb, L. J., and Tracey, J. G. (1981). Australian rainforests: patterns and change. In 'Ecological Biogeography of Australia, Vol. 1'. (Ed. A. Keast.) pp. 605-694. (Junk: The Hague.)

Webb, L. J., Tracey, J. G., and Jessup, L. W. (1986). Recent evidence for autochthony of Australian tropical and subtropical rainforest floristic elements. Telopea 2, 575-589.

Wells, R. T., and Callen, R. A. (Eds) (1986). 'The Lake Eyre Basin-Cainozoic Sediments, Fossil Vertebrates and Plants, Landforms, Silcretes and Climatic Implications.' (Geological Society of Australia: Sydney.)

Whiffin, T., and Hyland, B. P. M. (1994). Biogeography of Australian rain forest Lauraceae. In 'Origin and Evolution of the Flora of the Monsoon Tropics'. (Eds J. Clarkson, J. Neldner, B. Waterhouse, E. Brown, B. Jackes and B. P. M. Hyland.) pp. 33-34. (Australian Systematic Botany Society: Canberra.)

White, M. E. (1978). Tertiary plant fossils from Melville Island, NT. In 'The Geology and Mineral Occurrences of Bathurst Island, Melville Island, and Coburg Peninsular, NT'. (Ed. R. J. Hughes.) pp. 62-63. (Australian Bureau of Mineral Resources: Canberra.)

Wing, S. L., and Greenwood, D. R. (1993). Fossils and fossil climates: the case for equable continental interiors in the Eocene. Philosophical Transactions of the Royal Society, London Biological Sciences 341, 243-252.

Wolfe, J. A. (1990). Palaeobotanical evidence for a marked temperature increase following the Cretaceous-Tertiary boundary. Nature 343, 153-156.

Wolfe, J. A. (1993). A method of obtaining climatic parameters from leaf assemblages. US Geological Survey Bulletin 2040, 73.

Wopfner, H., Callen, R. A., and Harris, W. K. (1974). The Lower Tertiary Eyre Formation of the southwestern Great Artesian basin. Journal of the Geological Society of Australia 21, 17-52. 